\title{
Supply Chain Model of Fresh Fisheries in the Waters of Fakfak, West Papua: An Overview from the Perspective of Evaluation of Performance and Sustainability of Supply Chain
}

\author{
Christina Whidya Utami ${ }^{*}$, Victor Efendi ${ }^{2}$, Metta Padmalia ${ }^{3}$, Krismi Budi ${ }^{4}$, Dini Prativi ${ }^{5}$, \\ Gladys Gozal' ${ }^{6}$, Ignatius Teddy Saputra7 ${ }^{7}$, Alexander Wahyudi ${ }^{8}$
}

1,2,3,4,5,6,7,8 A International Business Management Department, Universitas Ciputra Surabaya.

*Corresponding author: whidyautami@ciputra.ac.id

Submission: 04 August 2020

Revised: 31 October 2020

Published: 29 November 2020

\begin{abstract}
This research intended to explore the performance of the management fresh fisheries supply chain and, eventually: to analyze the management, supporting facility and distribution and factors that affect the supply chain in Fafak, West Papua. The method used in this research is Soft System Methodology (SSM), which is expected to be able to solve problem through dialogue and qualitative method, as well as explicitly considers the aspect of ethic, sustainability and human values. There are seven stages in SSM, which includes: 1) supply chain problematic situation in fishery industry (2) revealing problem and creation of rich picture in building root definition/ relevant system (3) root definition/relevant system (4) reating conceptual model (5) comparing conceptual model with situation in the real world (6) formulating plan of maintenance action (7) execution of action plan. Problematic situation was analyzed using fish-bone diagram to help the designer to focus on the most important root cause in finding opportunity to have a sustainable maintenance and give critical guideline to devise sustainability. Based on the research result, it can be concluded that the condition of fishery industry in FakFak. West Papua, is in the less sustainable category. The performance of the fisherman and Cooperative supply chain showed very good and good performance, due to the Cooperative implementing order system. The management model in the fishery industry in FakFak, West Papua is reflected in model of the conceptual/ purposeful human activity system. The management model of the fishery industry in FakFak, West Papua is built by 20 system activities.
\end{abstract}

Keywords: Supply Chain, Supply Chain Model, Soft System Methodology, Fresh Fisheries

\section{INTRODUCTION}

Fisheries sector in Indonesia has given a pretty big contribution over the past 3 years, which were Rp.27,520.87 Billion (year 2012), Rp.32,104.07 Billion (year 2013), and Rp.37,442.32 Billion (year 2014). Gross Domestic Product (GDP) growth for fisheries kept showing growing positively until year 2018. In the third quarter of 2018, the GDP for fisheries reached Rp 59,984.3 billion. The number increased by 3.71 percent when compared to the GDP of fisheries in year 2017 in the same period, which only reached Rp. 57,838.0 billion. Therefore, it can be said that maritime sector is one of the strategic sectors in Indonesia. This country is expected to be a maritime country that is independent, developed, strong, and is based on the interest of the nation. Currently, Indonesia is a maritime country with $70 \%$ of its region being the sea. Indonesia has oceanic region of 5.8 million kilometer square, consisting of territorial region of 3.2g kilometer square and Exclusive Economic Zone region (EEZ) of 2.7 million kilometer square. Aside from that, there are 17,504 islands in Indonesia with coastline of 95,181km (BPS, 2015). Along with strategic environment development, the role of ocean has become significant and dominant in bringing progress for a country. If the strength and richness of the ocean is cultivated, then it will increase the wellbeing and safety of a country. One of the richness of the ocean that needs to be taken into consideration is the fisheries sector.

One of the regions in Indonesia that has potential in fishery that can be developed is Fakfak regency in West Papua. The potential of the fisheries and oceanic is the resource that stands out the most in Fakfak regency, especially with the existence of mangrove forest, estuary, coral reefs and natural seagrass beds, which is the breeding and growth location for a variety of fish and marine life. Aside from that, Business Competition Supervisory Commission also reported that West Papua province is the province with the highest potential in seaweed cultivation. In year 2012, seaweed in this province was set as the superior commodity and its development is centered in 5 strategic areas, which are Raja Ampat Regency, Kaimana Regency, Sorong Regency, Wandama Regency and one of which being Fakfak Regency.

Demand for the fresh fish catches from the fishermen is viewed as a commodity with high economical value, and is increasing every year. This is due to the increase in society's interest towards fishermen's catch products. The role of fishing port as the landing centre for fish is very important in fulfilling society's and industry's demand. 
Tabel 1. Fisheries Statistic in Fakfak Regency, Year 2017

\begin{tabular}{|c|c|c|c|c|c|}
\hline Description & 2013 & 2014 & 2015 & 2016 & 2017 \\
\hline Number of fishery household & 1,878 & 1,878 & 1,878 & 1,878 & 1,878 \\
\hline Number of fishermen & 2.332 & - & - & - & - \\
\hline Number of fishery boat/ship & 2.141 & - & - & - & - \\
\hline o Boat with no motor & 1,030 & 1,030 & 1,030 & - & 130 \\
\hline - Outboard motorboat & 1,022 & 1,022 & 1,022 & - & 569 \\
\hline $\begin{array}{l}\text { o Inboard motorboat } \\
\text { Number of fish catching tools }\end{array}$ & - & - & - & - & - \\
\hline o $\quad$ Fishing rod & 1,651 & 1,651 & 1,651 & 1,651 & 1,651 \\
\hline Basic & - & - & - & - & - \\
\hline Net & 457 & 457 & 457 & 457 & 457 \\
\hline Shark & - & - & - & - & - \\
\hline Cross & - & - & - & - & - \\
\hline floating & - & - & - & - & - \\
\hline o Parts & 18 & 18 & 18 & 18 & 18 \\
\hline Boat & - & - & - & - & - \\
\hline Raft & - & - & - & - & - \\
\hline
\end{tabular}

The management of supply chain in fresh fisheries commodity is much needed, since this commodity has economical value, high demand, and huge benefit for fishermen and the society. The need for the right supply chain management in fisheries commodity to add value, maintain stock and quality, as well as accessible to society. The catch produced in a fishery port is strongly affected by the demand for a commodity. Facility management and fish transportation management that is effective and efficient in the fresh fisheries supply chain can improve performance, efficient in terms of time and energy, lower operational cost, maintain quality of fish, as well as having wide range of distribution. Supply chain management is a series of approaches set to integrate supplier, businessman, warehouse and other storage efficiently so that the product can be produced and distributed to the consumers with the right quantity, quality, location, and time to minimize cost and satisfy consumer's needs (David et al., 2000 in Indrajit and Djokopranoto, 2002).

Transport of fish in the supply chain system is a distribution process in order to add economical value and benefit to the fish caught by the fishermen to be brought to fish market location. Location or area of fishing is usually located far from the market location, therefore, good delivery management is needed so that the quality of the fish is preserved until the place of destination. Fresh fish is export commodity with high economical value, and undergoes distribution and transportation process between countries located very far apart.

This study will review the performance of supply chain of fresh fisheries by referring to production, demand, distribution and marketing statistic of the catch. Formulating effective management strategy to improve the performance of fishery supply chain. This is intended so that the system in the chain that connects Cooperative with the supplier can work optimally and Cooperative's goal can be achieved. The aims of this research are as follows:

1. Analyzing management, supporting facility, and distribution and factors that have impact on supply chain in Fakfak, West Papua.

2. Measuring performance and formulate recommendations for steps of supply chain of fresh fisheries in Fakfak, West Papua.

\section{RESEARCH METHODOLOGY}

\section{Research Time and Location}

This research was conducted in the waters of Kokas, Fakfak, West Papua. The location of the research is focused on several transit docks in the fishing port, landing port, and other fish processing Cooperatives. This research was conducted from June to December of year 2019.

\section{Problem Approach Methodology}

This research used quantitative technique in formulating supply chain (Beamon 1998; Reiner and Trcka 2004; Apaiah and Hendrix 2005; Santoso et al. 2005; Wang and Shu 2007; Thanh et al. 2008; Ahumada and Villalobos 2009; Hammami et al. 2009; Schütz et al. 2009).

However, quantitative technique is hard to apply to small industries that have limitations on most recent software, as well as complex mathematical model (Dutta and Evrard 1999; OECD 2000; Celuch et al. 2007)

\section{Data Processing Methodology}

Soft System Methodology (SSM) can solve problem through dialogue and qualitative method, and explicitly considers aspects such as ethics, sustainability, and human values (Kunch et al. (2009), Mingers (2011)). SSM is (1) approach to overcome unstructured problem and is a process of action to understand the real situation of the problem, and to take action to fix it (Checkland and Poulter 2010); (2) approach that is promising to stakeholder to reduce uncertainty (Travella et al. 2012); (3) participatory approach to intervene in problematic situation and increase collaboration, communication, and information sharing in multi-organizational groups (Franco 2008, 2009); (4) frame work of solution that is specifically designed for situations whereby the essence of the problem is hard to be defined (Martin et al. 2008) and the stage of creating the rich picture and analysis 1,2,3 that is the source of information for stakeholder that is very valuable to fix the problematic situation (Georgiou 2008). This research is aimed to determine the condition of the fishery industry situation and design an ideal model for the management of the supply chain of the fishery industry that is sustainable in Fakfak, West Papua, using the method of Soft System Methodology.

\section{DATA ANALYSIS}

This research was conducted in Fakfak, West Papua, in the month of June to the month of December in year 2019. The type of data used are primary and secondary data. Primary data is in the form of opinion and thoughts from related experts for the attributes of sustainability 
indicator, fishery industry supply chain contributors, and also the data on Cooperative's operational activity. Primary data was obtained through questionnaire, expert survey, interview; expert panel and field observation. Secondary data is in the form of relevant rules and regulations; statistical data and information in various forms; program planning documents and budget (strategic planning, regional medium-term development planning, and others); various review results related to the development of fishery region; various monitoring and evaluation results, as well as other possible information data. The research was conducted through two stages, which are:

\section{Situational Analysis Stage of Fishery Industry Supply Chain}

Situational analysis of fishery industry supply chain was conducted to understand the profile, sustainability and performance of fishery industry using descriptive method. The profile of fishery industry obtained from statistical data was analyzed descriptively. The sustainability indicator was determined through exploration of sustainability indicators through in depth literature review and field observation. In this observation, interview with stakeholders was conducted. The result obtained was then used as the basis in doing brainstorming and discussion with 7 experts through the expert meeting forum. This process was done repeatedly, including through the comparison of indicators through the help of compare and contrast method, so that in the end an agreement can be obtained on the types and values of indicators of the sustainability indicator for fishery industry. These indicators were able to comprehensively reflect the performance of each dimension of fishery industry sustainability in Fakfak, West Papua. Purnomo et al. (2011) and Jaya et al. (2014) stated that the values of sustainability indicator for fishery industry obtained from the result of interview and questionnaire were then processed and analyzed using Rapfish (rapid appraisal for fisheries) technique. Rapfish is based on the ordination technique using Multi-Dimensional Scaling (MDS) (Fauzi and Anna 2002). The selection of MDS in Rapfish analysis was done, considering other multi-variate analysis and Multi- Attribute Utility Theory (MAUT), were proven to not yield stable result (Pitcher and Preikshot 2001). Rapfish analysis result obtained was then categorized based on sustainability index and status categories, referring to Hidayatno et al. (2009), as presented in Table 2.

Table 2. Sustainability Index and Status Categories

\begin{tabular}{ll}
\hline Index value & Category \\
\hline $0.00-25.00$ & Poor (not sustainable) \\
$25.01-50.00$ & Unsatisfactory (less sustainable) \\
$50.01-75.00$ & Satisfactory (sufficiently sustainable) \\
$75.01-100.00$ & Good (sustainable) \\
\hline
\end{tabular}

Source: Researcher data processing, 2020

Supply chain performance data was obtained from one of the fishery cooperative of fish catches commodity through observation, expert survey and in-depth interview. Data was processed and analyzed using Fuzzy AHP (Kabir 2011) and SCOR method (McCormack et al. 2008), Kafa et al. (2012). Criteria for supply chain performance was based on Rofik (2010), as presented in Table 3.

Table 3. Supply Chain Performance Criteria

\begin{tabular}{ll}
\hline Performance Score & Criteria \\
\hline $95-100$ & Excellent \\
$90-94$ & Above average \\
$80-89$ & Average \\
$70-79$ & Below Average \\
$60-69$ & Poor \\
$<60$ & Unacceptable \\
\hline \multicolumn{2}{l}{ Source: }
\end{tabular}

\section{Design Stage for the Ideal Fishery Industry Supply Chain Management Model}

The model for management of fishery industry supply chain was built following the 7 SSM stages, which are 1) supply chain problematic situation in fishery industry (2) revealing problem and creation of rich picture in building root definition/ relevant system (3) root definition/relevant system (4) creating conceptual model (5) comparing conceptual model with situation in the real world (6) formulating plan of maintenance action (7) execution of action plan. Problematic situation was analyzed using fish-bone diagram to help the designer to focus on the most important root cause in finding opportunity to have a sustainable maintenance and give critical guideline to devise sustainability (Jayswal et al. 2011).

\section{RESULTS AND DISCUSSION}

\section{Situational Condition of Fishery Industry in Fakfak, West Papua}

Statistical data and field observations show that majority of the fishery business in Fakfak, West Papua, are business in the micro to middle scale. Aside from that, the development of fishery industry still has some problems such as: (1) limited facilities and infrastructure; (2) limited transportation and communication facility; (3) limited human resources, access to capital and businessmen capacity; (4) lack of focus of commodity and industry management (5) weak organization and social culture. In terms of sustainability, from the results of interview and brainstorming with the experts, it was agreed that sustainability index is measured using 5 dimensions consisting of attributes, which are: (1) environment dimension (waste management level, efficiency of use of water, liquid waste potential volume); (2) social dimension (human resources skills, fishermen's income, industry partnership, absorption of industrial labor, industrial labor income); (3) technology dimension (suitability of technology type, product differentiation, product damage level); (4) economic dimension (unit net profit, profit margin, economic contribution, product quality and number of businesses); and (5) resources dimension (sufficiency of raw material, raw material continuity, raw material quality and raw material availability). Rapfish analysis result on expert's assessment for each dimension is shown in the form of index category and sustainability status of each dimension as presented in Table 4. 
Table 4. Index Category and Sustainability Status of Each Dimension

\begin{tabular}{lll}
\hline Sustainability dimension & Index value & Category \\
\hline Environment & 52,218 & Sufficiently sustainable \\
Social & 34,171 & Less sustainable \\
Technology & 50,646 & Sufficiently sustainable \\
Economical & 38,953 & Less sustainable \\
Resources & 47,573 & Less sustainable \\
\hline
\end{tabular}

Source: Researcher data processing, 2020

Based on Table 4, it can be known that environment and technology dimensions are currently in the sufficiently sustainable condition. In addition, social dimension, economic dimension and resources dimension are all in the less sustainable category. Each sustainability index dimension can be illustrated in the sustainability index kite diagram illustrated in Figure 1.

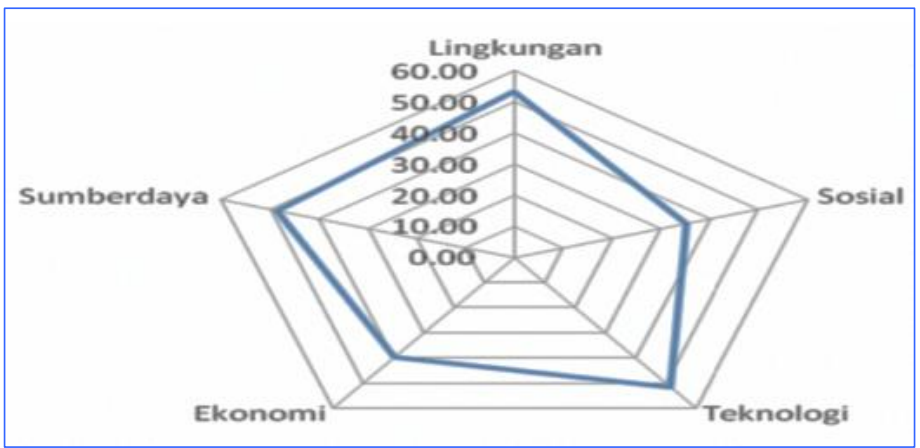

Fig 1. Sustainability Index Kite Diagram

Source: Researcher data processing, 2020

Furthermore, to find out the overview for the sustainability of the overall dimension, weighting was done by the experts on the sustainability index of each dimension obtained in order to obtain the multidimensional sustainability index value, and the result is presented in Table 5 . Multidimensional sustainability index analysis shows that the sustainability of fishery industry in Fakfak, West Papua, is in the less sustainable category (42.63).

Table 5. Multidimensional Sustainability Index

\begin{tabular}{llll}
\hline Sustainability dimension & Index value & Weight & Value x Weight \\
\hline Environment & 52,32 & 0,067 & 3,50544 \\
Social & 34,17 & 0,192 & 6,56064 \\
Technology & 50,65 & 0,117 & 5,92605 \\
Economical & 34,17 & 0,274 & 9,36258 \\
Resources & 47,48 & 0,364 & 17,28272 \\
\hline & \multicolumn{4}{c}{ Multidimensional sustainability index } & $\mathbf{4 2 . 6 3}$
\end{tabular}

In general, fishery industry in Fakfak, West Papua, markets their product well for domestic market and on the individual level. Performance analysis was conducted on one of the Cooperative of fish product processing. The fishery supply chain model of Fakfak, West Papua is presented in Figure 2.

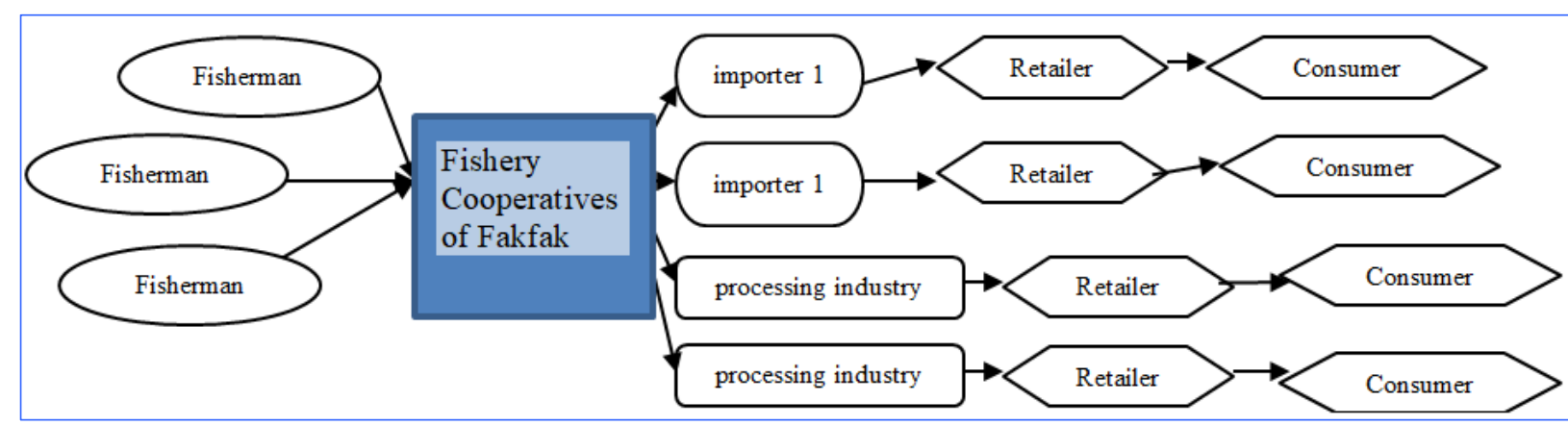

Fig 2. Fishery Supply Chain Model of Fakfak, West Papua

Source: Researcher data processing, 2020

Expert's opinion result through Fuzzy-AHP on the performance measurement matrix shows highest weight of each levels, which are: procurement $(0.338)$ in the business process level, quality $(0.538)$ in the performance parameter level, reliability $(0.350)$ in the performance attribute and arrival punctuality level (0.238) in the performance matrix level. These weights indicate that punctual arrival is a performance factor that needs to be paid attention to in the management of fishery supply chain performance. High weight in the attribute of performance reliability shows that reliability level needs to be paid attention to by the Cooperative in managing supply chain.

Performance measurement result shows that the total performance for fishermen and Cooperatives are 98.235 and 94.515 each. Compared to the performance standard by Rofik (2010), they are considered to be in the very good category (95-100). The very good performance of the 
fishermen supply chain is the result of support from the Fishermen Cooperative, in the form of briefing post capture and during sailing, providing ice and plastic, and offering satisfactory prices for fishermen partners. Cooperative is located in the centre area of fish arrival (Kokas, Ugar, Arguni and Furir villages), therefore, fishermen can immediately store their catch. Good Cooperative performance is the result of good relationship with the fishermen. Aside from that, fishermen Cooperatives only focus on fresh fish commodity and the product marketing process is conducted using order system, especially from "Tangguh LNG". Order system enables Cooperatives to better plan for production and only accept order after ensuring that they are able to fulfill the order, so that the chance for technical issue happening that is not within their control is slim.

\section{Ideal Model for Supply Chain Management System of Fishery Industry}

\section{Stage 1: PRoblematic Situation of FISHERY INDUStRY SuPPL Y CHAIN}

Fishery industry supply chain in Fakfak (Kokas,Ugar, Arguni and Furir) West Papua showed a complex situation. Fishermen's activity as the producer of the raw material for fishery is faced with climate problem, fish resources rarity threat due to the rampant action of illegal fishing and over fishing, and low level of skill and limited capital. This condition affects the performance of fishery Cooperative and managing smallmedium industry in fulfilling supply and quality of the raw material. This impacts on the low level performance Cooperative and managing small-medium industry due to the inability to achieve capacity and quality of the product. As a result, consumer's need for fishery product can't be fulfilled.

This situation is even more complex due to the condition and characteristic of the people in Fakfak region (Kokas,Ugar, Arguni and Furir), West Papua. The condition of the region is in the form of islands and the minimum infrastructure resulted in high logistic cost and accommodation cost for access between islands. This condition impacts on the high price level for fishery products and minimum realization of cultivation programs for fishermen society, due to the insufficient fund and the dependence of regional government on the central government in terms of program funding. The complexity of the problem resulted in the difficulty in realizing industrialization strategy for fishery and development for sustainable fishery, as well as national development. This condition is reflected in the analysis result for sustainability and performance of the supply chain, that showed that fishery industry in Fakfak, West Papua, is in less sustainable position and the performance of the supply chain in terms of fulfilling market's demand is still done based on order system, due to the inability to ensure the continuity of the source of supply of the raw material.

\section{StAGE 2 : PROBLEM REVELATION AND RICH PICTURE CREATION}

Based on the problem situation in stage 1, cause and result analysis was conducted using fish-bone diagram with all the stakeholders and the root cause of the problem in the supply chain of fishery industry in Fakfak, West Papua was obtained to reveal the situation of the problem. The result of the fish bone analysis was arranged as issues in the fishery industry supply chain in Fakfak, West Papua, which are: (1) low competitiveness of fishery product (2) lack of development in domestic market for fishery products and securing the quality of the fish; (2) access to capital for fish business is still limited; (4) quality of the majority of the fishermen is still relatively low; (5) illegal activities, unregulated fishing (6) over fishing in the waters; (7) weak institutional capacity of supervisors and law enforcement; (8) data system for fishery that is still not reliable and still partial. The situation of problem in the supply chain of fishery industry in Fakfak, West Papua, is illustrated in the form of rich picture in Figure 3.

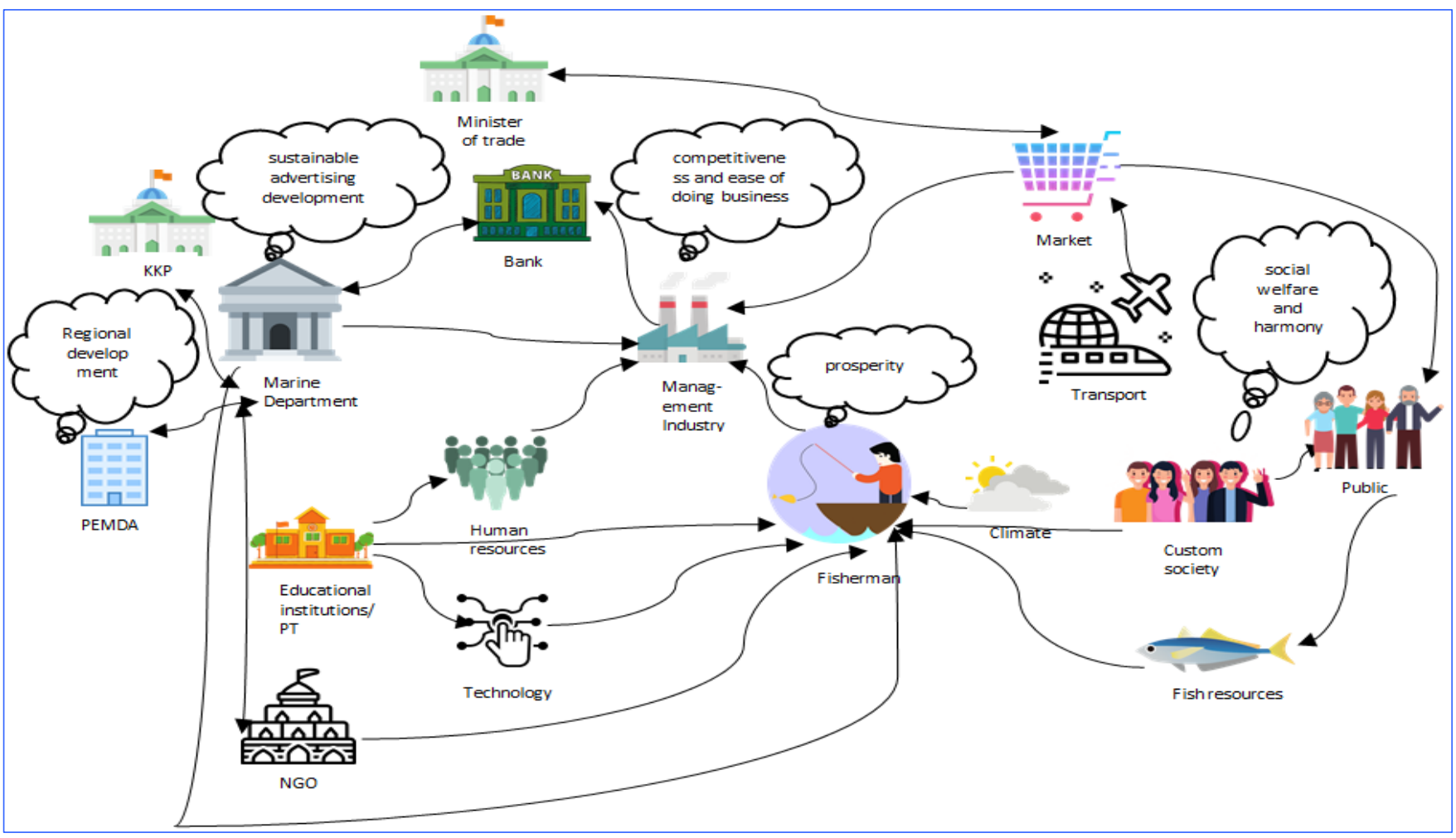

Fig 3. Rich Picture of Supply Chain of Fishery Industry in Fakfak, West Papua

Source: Researcher data processing, 2020 


\section{STAGE 3 : ROOT DEFINITION/RELEVANT SYSTEM}

Hardjosoekarto (2012) stated that formulation of root definition was done as the basis in creating conceptual model that is formulated using $\mathrm{PQR}$ formula, that represents matter by conducting $\mathrm{P}$ through or by $\mathrm{Q}$ in order to achieve R. Root definition is tested and perfected using analysis tool CATWOE $(\mathrm{C}=$ customer, $\mathrm{A}=$ actors, $\mathrm{T}=$ transformation, $\mathrm{W}=$ worldview, $\mathrm{O}=$ owners, $\mathrm{E}=$ environmental constraint $)$. Root definition and CATWOE are sources of activity creation in purposeful activity model supply chain management system for sustainable fishery industry in Fakfak, West Papua.

Based on the result in stage 2, root definition and CATWOE can be formulated as follows: "The Ministry of Maritime Affairs and Fisheries, the Office of Maritime Affairs, Regional Government and supply chain operators (O) create a sustainable fishing industry and the implementation of activities in the fisheries sector that is reliable and has global competitiveness (W), which integrates all units in the supply chain and coordinates the flow of material, information and finance, starting from the aspects of production, downstream industry (handling and processing), to marketing ( $\mathrm{T}$ ) from fishermen, processing industries (C) in the entire supply chain through effective and efficient mechanisms (E) and central and regional institutional coordination(A) related to the quality and standardization of fishery products, distribution, facilities, infrastructure and data and information on fisheries (T)"

\section{STAGE 4 : MODELLING ROOT DEFINITION/ RELEVANT SYSTEM (CONCEPTUAL MODEL)}

According to Hardjosoekarto (2012), the core of system thinking is the creation of conceptual model as intellectual tool used to discuss situation in the real world that is deemed problematic. The root definition that is subsequently obtained is modelled to be a conceptual model that is called purposeful human activity system (PHAS), which shows the correlation between the activities needed to realize the transformation process. Based on this root definition, then the conceptual model/ purposeful human activity system on the management of fishery industry supply chain in Fakfak, West Papua can be made as in Figure 4.

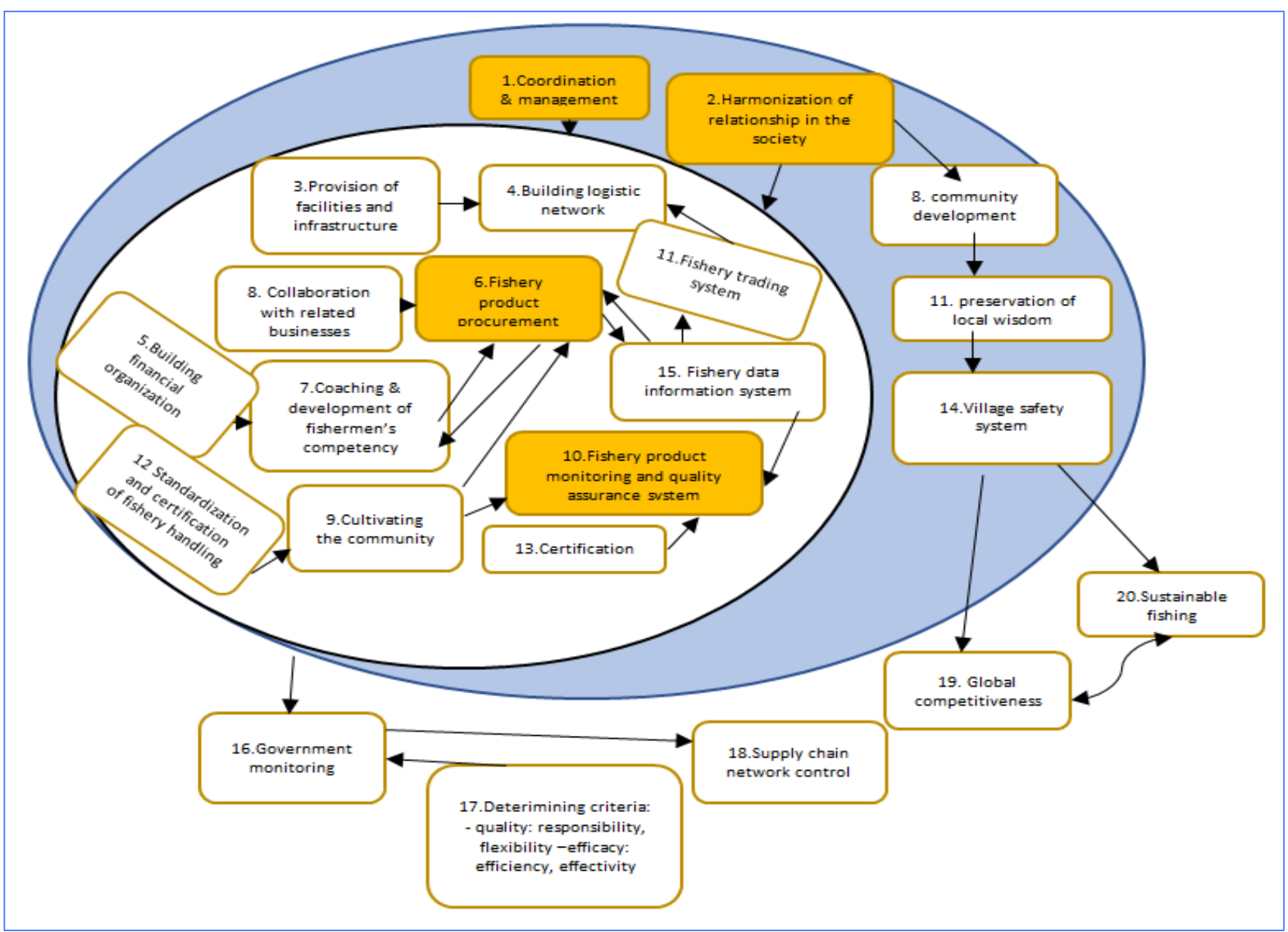

Fig 4. Conceptual Model of Supply Chain Management of Sustainable Fishery Industry in Fakfak, West Papua Source: Researcher data processing, 2020

Figure 4 shows that there are 20 activities that need to be done in order to achieve a sustainable model for the management system of fishery industry supply chain in Fakfak (Kokas,Ugar, Arguni and Furir), West Papua. The success of the conceptual model can be measured using the 3E criteria (Efficacy, Efficiency, and Effectiveness) by having coordination between the actors in the supply chain using minimum resources and time. Achieving performance for the fishery industry supply chain in FakFak (Kokas,Ugar, Arguni and Furir), West Papua.

\section{StAGE 5 AND 6 : COMPARING CONCEPTUAL MODEL WITH THE REAL WORLD SITUATION AND CORRECTIVE ACTION}

Process of comparing with real world resulted in gaps that need corrective action. Part of the execution of stage five and six SSM can be seen in Table 5. Dialogue and debate based on visual material are allowed. This is more efficient than simply through dialogue and debate (White 2006). Visual material will increase stakeholder's involvement since they are also involved in action taking (Franco 2006). 


\section{StAge 7 SSM : Action AND ACTIVITY PLAN}

Formulation of the action plan is recommended to be done by the relevant parties based on the result of Focus Group Discussion. This research did not conduct stage 7 of SSM.

\section{CONCLUSION}

Based on the result of the research, it can be concluded that the fishery industry condition in Fakfak (Kokas,Ugar, Arguni and Furir) West Papua is in the less sustainable category. The performance of the fishermen and Cooperative supply chain shows to be very good and good, due to the Cooperative (especially for Cooperative in Arguni) implementing the order system. Management model of fishery industry in Fakfak, West Papua is built by 20 system activities.

\section{SUGGESTION}

Performance measurement needs to be conducted to measure the performance of the supply chain by involving higher number of Cooperative and with other commodity such as seaweed. Improvement on management system of fishery industry supply chain in Fakfak (Kokas, Ugar, Arguni and Furir), West Papua, can be achieved by conducting activities related to the conceptual/ relevant system model built.

\section{Reference:}

Ahumada O, Villalobos JR. 2009. Invited Review. Application of Planning Models in the Agri-Food Supply Chain: A review. European Journal for Operational Research. 196(1): 1-20.

Apaiah RK, Hendrix EMT. 2005. Design of a Supply Chain Network for Pea-Based Novel Protein Foods. Journal of Food Engineering. 70(3): $383-391$.

Beamon BM, 1998. Supply Chain Design and Analysis: Models and Methods. International Journal of Production Economics. 55(3): 281-294.

Celuch K, Murphy GB, Callaway SK. 2007. More Bang for Your Buck: Small Firms and the Importance of Aligned Information Technology Capabilities and Strategic Flexibility. Journal of High Technology Management Research. 17(2): 187-197.

Checkland P, Poulter J. 2010. Soft System Methodology. London : Published In Association with Springer-Verlag.

Dutta S, Evrard P. 1999. Information Technology and within European Small Enterprises. European Management Journal. 17(3): 239-251

Fauzi, A. and S. Anna. 2002. Penilaian Depresiasi Sumberdaya Perikanan sebagai Bahan Pertimbangan Penentuan Kebijakan Pembangunan Perikanan. Jurnal Pesisir dan Lautan. 4(2): 36-49.

Franco LA. 2006. Forms of Conversation and Problem Structuring Methods: a Conceptual Development. Journal of the Operation Research Society. 57(7): 813821.

Franco LA. 2008. Facilitating Collaboration with Problem Structuring Methods : A Case Study of an Internal Construction Partnership. Group Decession Negotiation. 17(4): 267-286.

Franco LA. 2009. Problem Structuring Methods as Intervention Tools: Reflections from Their Use with Multival Team. Omega. $37(1)$ : 103-203.

Georgiou I. 2008. Making Decisions in the Absence of Clear Facts. European Journal of Operational Research. 185(I): 299-321.

Hammami R, Frein Y, Hadj-Alouane AB. 2009. A Strategic-Tactical Model for Supply Chain Design in the Delocalization Context: Mathematical Formulation and Case Study. International Journal of Production Economics. 122(1): 351-365.

Hardjosoekarto S. 2012. Construction of Social Development Index as Theoretical Research Practice In Action Research by Using Soft System Methodology. Sys.Pract.Action Res [Online] .

Hidayatno M, Supandi S, Yahya S, Amin LI 2009. Analisis Keberlanjutan Kakao Rakyat Di Perbatasan Pulau Sebatik, Kabupaten Nunukan, Propinsi Kalimantan Timur. Jurnal Agro Ekonomi. 27: 213-229.

Indrajit RE dan R Djokopranoto. 2002. Konsep Manajemen Supply Chain Cara Baru Memandang Mata Rantai Penyediaan Barang. Jakarta (ID). Grasindo.

Jaya R, Machfud, Raharja S, Marimin. 2014. Prediction of Sustainale Supply Chain Management for Gayo Coffee using System Dynamic Approach. Journal of Theoritical and Applied Information Technology. 70: 372-380.

Jayswal A, Li X, Zanwar A, Lou HH,Huang Y. 2011. A Sustainability Root Cause Analysis Methodology and its Application.

Kabir G, Hasan MAA. 2011. Comparative Analysis of AHP and fuzzy AHP models for Multicriteria on Inventory Classification. Journal of Fuzzy Logic Systems. 1: $1-16$

Kafa N, Hani Y, Mhamedi A E. 2013. Sustainability Performance for Green Supply Chain Management. IFAC Procedings Volumes. Volume 46, Isuue 24, September 2013. Page 71-78. 6th IFAC Conference on Management and Control of Production and Logistics. Elsevier. http://www.sciencedirect.com/science/arti cle/pii/S1474667016321681 Diunggah tanggal 22 April 2014.

[Kemdag] Kementrian Perdagangan Indonesia. 2010. Kebijakan Perdagangan Dalam Pengembangan Distribusi Hasil Perikanan. Rapat Koordinasi Pengembangan Sistem Jaringan Distribusi Hasil Perikanan. Jakarta: Kementrian Perdagangan Indonesia.

Martin E, Winarno B, Purnomo H, Wijayanto, N. 2008. Penatakelolaan Kawasan Hutan Rawan Konflik Melalui Pendekatan Metodologi Sistem Lunak : Kasus Hutan Penelitian Benakat, Sumatera Selatan. Jurnal Penelitian Sosial dan Ekonomi Kehutanan. 5(3): 179-202.

McCormack K, Marcelo Bronzo Ladeira, Marcos Paulo Valadares de Oliveira, (2008) "Supply Chain Maturity and Performance in Brazil", Supply Chain Management. An International Journal. 13(4): 272-282.

Mingers J. 2011. Ethics and OR : Operationalising Discourse Ethic. European Journal of Operational Research. 210(1): 114-124.

Pemerintah Fak Fak Irian Barat. 2014. Reformulasi Master Plan Maluku Lumbung Ikan Nasional 2015-2025. Pemerintah Fak Fak Irian Barat.

Pitcher TJ, Preikshot DB, 2001. Rapfish: A Rapid Appraisal Technique to Evaluate the Sustainability Status of Fisheries. Fisheries Research. 49(3): 255-270.

Purnomo BH, Machfud, Hermawan A, Wiyono E. 2011. Model Prediksi Keberlanjutan Sumber Daya dan Ekonomi pada Agroindustri Teri Nasi. Jurnal Teknologi Industri Pertanian. 21: 163-175.

Rofik M A. 2010. Skripsi. Kinerja Rantai Pasok pada Industri Seafood (Studi Kasus di PT Kelola Mina Laut). Bogor. IPB. 92 hlm.

Santoso T, Ahmed SA, Goetschalckx M, Shapiro A. 2005. A Stochastic Programming Approach for Supply Chain Network Design Under Uncertainty. European Journal of Operational Research.167: 96-115.

Schütz P, Tomasgard A, Ahmed S. 2009. Supply Chain Design Under Uncertainty Using Sample Average Approximation and Dual Decomposition. European Journal of Operational Research. 199: 409-419.

Thanh PN, Bostel N, Péton O. 2008. A Dynamic Model for Facility Location in the Design of Complex Supply Chains. International Journal of Production Economics. 113(2): 678-693.

Travella E, Carsten NH. 2012. Enhanching the design and Management of Local Organik Food Supply Chain with Soft System Methodology. International Food and Agribusiness Management Review. 15(2): 48-68.

Wang J, Shu YF. 2007. A Possibilistic Decision Model for New Product Supply Chain De- sign. European Journal of Operational Research. $177(2)$ : 1044-1061.

White L. 2006. Evaluating Problem-Strcturing Methods : Developing an Approach to Show the Value and Effectiveness of PSMS. Journal of the Operational Research Society. 57(7): 842-855. 